\title{
Proceeding
}

Supplementary Issue: Spring Conferences of Sports Science. Costa Blanca Sports Science Events, 19-20 June 2020. Alicante, Spain.

\section{Tendinopathies of the hip and pelvis in athletes: $A$ narrative review}

\author{
FELICE SIRICO $\triangleleft$, STEFANO PALERMI, BRUNO MASSA, BRUNO CORRADO \\ Department of Public Health, University of Naples "Federico II", Naples, Italy
}

\begin{abstract}
Tendon disorders represent some of the most frequent musculoskeletal complaints worldwide. In the athletic population, tendinopathy could affect different anatomical districts. Tendons surrounding hip and pelvis are frequently involved due to overuse and high functional demands in the athletes. These disorders negatively impact on sport performance, since they are a long-lasting clinical condition requiring a multimodal management. Great trochanter pain syndrome, proximal hamstring tendinopathy, insertional adductor tendinopathy and ileopsoas tendinopathy are the most common clinical conditions involving tendon structures of the hip and pelvis. Due to the anatomical complexity of the region, the relationship with pelvic organs, the demographic and anthropometric characteristics of the athletes, the differential diagnosis between these musculoskeletal disorders and other diseases is often difficult to conduct and some therapeutic options are challenging. Modification of risk factors, changes in training protocols, some specific therapeutic exercise programs and rehabilitation procedures have been proposed as an efficient conservative management strategy, guarantying a complete recovery of athletic function. Surgical approaches are required in a specific subset of patients. This narrative literature review aims to summarize current understanding and areas of ongoing research about the clinical features, diagnostic keys and therapeutic options of the main clinical tendinopathies surrounding hip and pelvis.
\end{abstract}

Keywords: Tendinopathy; Hip; Pelvis; Sport, Athlete.

Cite this article as:

Sirico, F., Palermi, S., Massa, B., \& Corrado, B. (2020). Tendinopathies of the hip and pelvis in athletes: A narrative review. Journal of Human Sport and Exercise, 15(3proc), S748-S762. doi:https://doi.org/10.14198/jhse.2020.15.Proc3.25

Corresponding author. University of Naples "Federico II" - Department Public Health, via S. Pansini 5, 80131, Naples, Italy. E-mail: felice.sirico2@unina.it

Supplementary Issue: Spring Conferences of Sports Science. Costa Blanca Sports Science Events, 19-20 June 2020. Alicante, Spain.

JOURNAL OF HUMAN SPORT \& EXERCISE ISSN 1988-5202

(c) Faculty of Education. University of Alicante

doi:10.14198/jhse.2020.15.Proc3.25

S748 $|2020|$ Proc3 | VOLUME 15

(c) 2020 University of Alicante 


\section{INTRODUCTION}

Tendinopathies represent a complex issue among musculoskeletal disorders. They have a wide etiology, including chronic diseases and traumatic injuries, with a recognized inflammatory pattern as one of the causal factors (D’Addona et al., 2017).

The structure and the function of the tendons could be impaired by several systemic metabolic, genetic and neurological diseases, such as diabetes (Batista et al., 2008), endocrinological disfunctions (hypothyroidism) (Oliva et al., 2016), genetic enzymatic defect (Corrado et al., 2019) and spasticity (Corrado et al., 2019).

In common clinical practice tendinopathies are related to acute or chronic trauma, caused by overload and overtraining beyond the healing capabilities of the tendon itself. For these reasons, tendinopathies represent one of the most frequent orthopaedic diagnosis (Andarawis-Puri et al., 2015). Lots of human tendon-related procedures take place annually worldwide with significant socio-economic repercussions (Abbah et al., 2014). Some modifiable and not modifiable risk factors are involved in developing tendinopathy, like age, gender, sex (Morton et al., 2017), occupational exposure (Hopkins et al., 2016) and different pharmacological molecules (Knobloch, 2016).

Preventive approaches have been proposed over the year to limit the incidence of tendinopathies, such as adopting specific protocol of therapeutic exercises (Littlewood et al., 2015), monitoring training load (Mascaró et al., 2018) (Ardigò et al., 2020), analysing of sport specific gesture (Rosa et al., 2016) and practicing regular physical activity to contrast sedentarism and avoiding drop-out from sports (Montesano et al., 2016), although these approaches are applied rarely in general population (Palermi et al., 2020).

Tendon disorders are very common in sports and any anatomical district may be interested depending on the type of sport practiced (Loiacono et al., 2019). For position and role, hip and the surrounding tendons are overstressed and often overloaded, especially in athletes (Schilders et al., 2013): this could lead to the developing of several tendinopathies, among which the differential diagnosis is often complicated (Frizziero et al., 2016). The anatomy of hip is extremely complex, and several muscles interact and contribute to its functioning: flexors (iliopsoas, rectus femoris, pectineus and sartorius), extensors (gluteus maximus and hamstrings - semimembranosus, semitendinosus and biceps femorii), adductors (adductors longus, brevis and magnus, pectineus and gracilis), abductors (gluteus medius, gluteus minimus, piriformis and tensor fascia latae), external rotators (biceps femoris, gluteus maximus, piriformis, assisted by the obturators, gemilli and quadratus femoris) and internal rotators (anterior fibres of gluteus medius and minimus, tensor fascia latae) (Wilson \& Furukawa, 2014). It is estimated that injuries to the hip or pelvis represent approximately 2$5 \%$ of all sports injuries and up to $11 \%$ of running-related injuries (Heiderscheit \& McClinton, 2016).

The management of tendinopathies is changing with the progression of the research and the growing evidences on this argument (Grimaldi et al., 2015). Currently, the treatment should include early functional treatments, rather than rest and immobilization (Lustenberger et al., 2011). Several therapeutic options are allowed: eccentric and concentric exercise, extra-corporeal shock wave therapy (ESWT), physical therapy (therapeutic ultrasound, low level laser therapy (LLLT) and hyperthermia (D'Addona et al., 2016)), splintingbracing and orthoses and manual therapy (Kaux et al., 2011). The biological effectiveness of some physical therapy, like electromagnetic field, has been proved in some cells (like chondrocytes), but poor results are available about tenocytes' activities (Servodio lammarrone et al., 2016). Injection therapy has been largely adopted over the year using steroid, blood derivates, collagen and other drugs (Sirico et al., 2017) (Corrado et al., 2019). Nowadays, these procedures are commonly performed exactly to the involved anatomical 
structures; technical equipment, like ultrasound guidance, are able to provide anatomical, functional and biomechanical information about the architecture of several components of musculoskeletal systems, providing qualitative information about the characteristics of involved tissues (with techniques like the elastography) (Vola et al., 2018) (Corrado et al., 2019).

In this narrative review we aim to summarize key characteristics about clinic, diagnosis and therapy of hip and pelvis tendinopathies.

\section{GREAT THROCANTER PAIN SYNDROME (GPTS)}

Several definitions, over the years, have been given to Greater Trocanther Pain Syndrome (GTPS), as "hip periarthritis" and "trochanteric bursitis" (Bird et al., 2001) (Kingzett-Taylor et al., 1999). However, in most cases, the diagnosis of trochanteric bursitis alone is inappropriate (Shbeeb et al., 1996), since co-existence of both bursitis and tendinopathy often occurs (Long et al., 2013). Particularly, GTPS contains a range of causes including gluteal medius and minimus tendinopathy and/or tears, trochanteric bursitis and external coxa saltans (Strauss et al., 2010) (Connell et al., 2003) (Bird et al., 2001).

GTPS is the most frequent cause of pain in the trochanter region (Strauss et al., 2010) (Connell et al., 2003), and the most common tendinopathy in lower limbs (Fitzpatrick et al., 2019), being the leading cause in 10$20 \%$ of patients presenting with hip pain (Lievense et al., 2005). It is more frequent in women and the mean age at presentation is over 50 years (Segal et al., 2007). It is a widespread condition in runners (Grimaldi et al., 2015). Risk factors for GTPS include female gender, obesity, knee pain, and low back pain, other than scoliosis, leg length discrepancy and articular conditions of lower limbs (Fearon et al., 2013). However, its pathogenesis remains unclear (Genth et al., 2012) (Chi et al., 2015). GTPS has been shown to negatively impact quality of life, such as other similar conditions do (hip osteoarthritis) (Fearon et al., 2014).

There are no established diagnostic criteria for GPTS; nevertheless, the key clinical features are lateral hip pain near the greater trochanter, different from posterior hip (sub gluteal or retro trochanteric disease) and anterior hip (articular hip pathology). Pain increases with walking, prolonged standing, upright activity, climbing stairs and with direct pressure when lying on the painful side (Brunker et al., 2017). Local tenderness to palpation of the great trochanter could be considered as a diagnostic feature too. Single clinical tests for GTPS lack validity, but a combination of tests can be used to increase the diagnostic accuracy (Speers \& Bhogal, 2017): i.e. a combination of tenderness to palpation of the great trochanter, of standing on one leg for 30 seconds, of resisted external derotation test, of passive adduction with resisted abduction, of FABER test. Imaging studies could be helpful to obtain a diagnosis, including conventional radiography and ultrasonography. MRI should be reserved for specific situations (Chowdhury et al., 2014). Differential diagnosis of lateral hip pain includes (Ho \& Howard, 2012): GTPS, hip joint disease and lumbar spine disease (referred).

GTPS is a self-limited condition in the majority of patients. Therefore, the goal of treatment is to relieve symptoms and prevent disability. Initial therapy for patients with GTPS includes a combination of pain relief (oral nonsteroidal anti-inflammatory agents (NSAIDs) or a glucocorticoid injection), exercise therapy and activity modification. The treatment with corticosteroids injections has been shown to be effective (Labrosse et al., 2010), relieving pain and reducing inflammation within three months after the administration (Stephens et al., 2008) (Coombes et al., 2013), whether studies with a long follow-up are still missing. Conservative treatment is the gold standard for GTPS, even if there is currently no evidence-based protocol for its management (Lustenberger et al., 2011). Exercise and load management are the cornerstone of an effective 
tendinopathy management (Mellor et al., 2016): exercises usually involve isometric loading of hip abductors and flexors, as well as calf strengthening exercises (Mellor et al., 2016) (Ganderton et al., 2018). Activity modifications can be incorporated into activities of daily living, recreation and sports (Ganderton et al., 2018): minimize stair climbing, avoid hip adduction across the midline, avoid crossing legs while sitting, stand with equal weightbearing through lower limbs. Patients who have not improved after at least 12 months of conservative therapy or who have muscle tears on MRI, should be referred for surgical intervention (Del Buono et al., 2012).

\section{PROXIMAL HAMSTRING TENDINOPATHIES (PHT)}

Proximal hamstring tendinopathies (PHT) is a painful syndrome localized in the ischiatic region that may extend to the posterior thigh (Cushman \& Rho, 2015). The proximal hamstrings originate from the ischial tuberosity, except from the short head of the biceps femoris. Indeed, their origin is double: the semimembranosus (ventral and lateral) and the conjoint tendon, comprised of both the semitendinosus and long head of the biceps femoris (Feucht et al., 2015). Different parts of hamstring can be affected by tendon pathology. The semimembranosus is one of the most commonly affected parts in PHT (Lempainen et al., 2015), followed by the common hamstring tendon, biceps femoris and semitendinosus (Benazzo et al., 2013).

While hamstring injuries at the musculotendinous junction are relatively common with athletic participation, proximal hamstring injuries occur rarely (Ahmad et al., 2013). PHT is commonly seen in long distance and sprinting runners (Puranen \& Orava, 1988), football and hockey players (Fredericson et al., 2005), since these activities involve frequent changes of direction. It is also common in sedentary people (Jesus et al., 2015). Key risk factors are represented by poor lumbo-pelvic control, thigh muscle imbalances and hamstring weakness (Jayaseelan et al., 2014). Compression of the tendon at its attachment during hip flexion/adduction has been seen to be an important etiological factor, (Cook \& Purdam, 2009), other than a shearing force in hamstring attachment (Hamming et al., 2015) and an increased hip flexion angle (Harvey et al., 2015).

As a result of both their reduced incidence and variable masked presentation, these injuries are often misdiagnosed, resulting in prolonged periods of disability and delays in treatment (Degen, 2019). Since there is no significant swelling, inspection is not so useful in the diagnostic process. Palpation over the ischium can reproduce some tenderness in severe cases. Hip and knee range of motion (ROM) is usually preserved; therefore, specific physical examination manoeuvres should be performed to elicit symptoms (Degen, 2019): the bent-knee stretch, the modified bent-knee stretch and the Puraven-Orava test are used as passive stretch tests in the diagnosis of PHT (Cacchio et al., 2012) (Cook \& Purdam, 2014). The pain is often felt on the lower gluteal region, radiating along the hamstrings (Fredericson et al., 2005). The onset is mostly gradual, presenting as a chronic condition (Puranen \& Orava, 1988). This syndrome must be distinguished from ischiofemoral impingement, gluteal muscle tear, pelvis stress fracture and rupture of the proximal hamstring tendon (Goom et al., 2016), other than sciatic nerve pain (Podschun et al., 2013). MRI is required to confirm the diagnosis and to quantify the amount of the injury (Zissen et al., 2010). Ultrasound is also used, but with poorer results (Mccormack, 2012) (De Smet et al., 2012).

Eccentric exercises have been considered the cornerstone of insertional hamstring tendinopathy treatment, in spite of low grade supportive evidences (Goom et al., 2016) (Beyer et al., 2015). Goom et al. (Goom et al., 2016) recommend four progressive rehabilitation stages: isometric hamstring load, isometric hamstring load with minimum hip flection, isotonic exercise in increased hip flexion and energy storage loading. Training load management is essential in the management of tendon-related pain: it is advisable to limit pain producing compressive and energy storage load activities (i.e. increased hip flexion), until there is a reduction in pain 
irritability (Goom et al., 2016). Aggravating sporting activities may be replaced with cross-training both to maintain cardiovascular fitness and to reduce physical effort (Goom et al., 2016). Rehabilitation should incorporate the whole kinetic chain (Cook \& Docking, 2015). Injections with platelet rich plasma (PRP) may have interesting implications (Dallaudière et al., 2014) (Davenport et al., 2015), even if there are no high quality studies to support its use (Fader et al., 2014) (Wetzel et al., 2013). Limited evidences are available on the effectiveness of dry needling and soft tissue techniques (Jayaseelan et al., 2014). Massage and manual therapy can be useful in PHT, especially when these are used to address tone and restriction in the kinetic chain (Goom et al., 2016). When conservative treatment fails, the patient may need surgery to decrease improve its symptomatology and prognosis (Brunker et al., 2017).

\section{INSERTIONAL ADDUCTOR TENDINOPATHY}

Chronic recurrent groin pain could be determined by several pathologies, including insertional adductor tendinopathies. Adductor tendinopathy describes a number of conditions that develop in and around the tendon (Khan et al., 1999), often due to chronic overuse. The adductors consists of 3 muscles: adductor brevis (from the inferior pubic ramus, to the medial ridge of linea aspera), adductor longus (from the front side of the pubic bone under the pubic tubercle, to the medial ridge of linea aspera) and adductor magnus (from the inferior pubic ramus and ischial tuberosity, to the medial ridge of linea aspera and the adductor tubercle). These muscles help to stabilize the pelvis and pull the legs towards the midline (adduction) and are innervated by obturator nerve (L2-L4).

Groin pain is a common problem in athletes (Mens et al., 2006), and it could be adductors related. Adductor related groin pain can be due both to muscle strain, tendon disease, or a combination of these two (Martens et al., 1987) (Braun \& Jensen, 2007) (Topol \& Reeves, 2008) (Ashby, 1994). Many athletes present to clinicians with a history of acute or chronic groin pain, ranging from a single traumatic event to repeated microtrauma (Martens et al., 1987). However, multiple pathologies may exist in individuals with chronic groin pain (Braun \& Jensen, 2007), adding complexity to its diagnosis and management (Biedert et al., 2003), such as inguinal hernia or reproductive system diseases. Insertional adductor tendinopathy is common in sports involving changes of direction, acceleration and deceleration, tackles and kicking, such as running, football, horse riding, gymnastics and swimming (Fricker, 1997) (Robinson et al., 2004). The repetitive nature of these movements in some of these sports heavily stresses the adductor tendon (Biedert et al., 2003), making predisposed to injury. Also stretching of the adductor tendons (Biedert et al., 2003) and sudden increasing in training could contribute to the genesis of this syndrome.

Due to the complexity of groin pain in athletes and the difficulty to specifically diagnose the accurate pathological structure, it is important to combine clinical examination and imaging features ( $X$ ray, ultrasound, MRI) to appropriately manage these problematic patients. Delay in diagnosis and treatment may result in undesired complications and lost of time from sport participation. Adductor tendinopathy should be suspected in cases of groin pain with localized tenderness, weakness and unilateral pain, especially during isometric adduction of the hip muscles (Avrahami \& Choudur, 2010). Radiological confirmation may require plain radiographs to exclude avulsion injury or heterotopic calcification (Kälebo et al., 1992). MRI is also the imaging of choice (Robinson et al., 2004), to identify the anatomical cause of groin pain. Indeed, the causes of groin pain can be numerous due to musculotendinous, neurologic and reproductive system structures in that area (Mens et al., 2006).

The aim of rehabilitation is to restore muscle and tendon properties (Hölmich et al., 1999). Conservative management may include cessation of physical activity and load management; local anesthetic/corticosteroid 
injection and anti-inflammatory drugs can be used along with graduated strengthening of the core muscles, passive physical therapy modalities and stretching exercises (Topol et al., 2005) (Robinson et al., 2004). Recent papers suggest that eccentric based exercise program is the most effective for improving both pain and function in this tendon pathology (Cook \& Purdam, 2009). Heavy-slow eccentric and concentric exercises still represent valid therapeutic options. For subjects with recurrent adductor tendinopathy, surgery treatment is a therapeutic option too (Hsu, 2011).

\section{ILIOPSOAS TENDINOPATHY}

lliopsoas syndrome is a series of pathologies causing groin pain, and it is composed by iliopsoas tendinopathy, internal snapping hip and iliopectineal bursitis (Tyler et al., 2014). Iliopsoas tendinopathy is an inflammation of the tendon of this muscle, often related to a bursitis, due to their close proximity (Nanni, 2017). It is a composite muscle formed from the psoas major and the iliacus muscle; the psoas major joint the iliacus at the level of the inguinal ligament and crosses the hip joint to insert on the lesser trochanter of the femur. lliopsoas is a powerful hip flexor, important for normal hip strength and function (C. N. Anderson, 2016).

There are few epidemiological data in the literature on the actual incidence of the iliopsoas tendinopathy, probably linked to its rare incidence, its misdiagnosis, or its diagnosis under different name (i.e. snapping hip syndrome). In a large sample of consecutive hip MRI, its prevalence was $0.66 \%$ (Bui et al., 2008). It is more commonly found in young people with prevalence in females (Dydyk \& Sapra, 2020). lliopsoas tendinopathy occurs most frequently as a result of overuse in sports requiring repetitive hip flexion and external rotation movements (Tyler et al., 2014), such as football, artistic gymnastics, canoeing, uphill walking (Milic et al., 2020) and dancing (Tyler et al., 2014) (Laible et al., 2013) (Brunot et al., 2013). This condition in sedentary subjects could be secondary to hip arthroplasty and arthritis (Tyler et al., 2014).

Iliopsoas tendinopathy presents more as anterior hip pain in younger athletes, especially after a rapid growth spurt (Rauseo, 2017). Examination usually reveals painful hip flexors. When evaluating a patient with iliopsoas tendinopathy, the back and pelvis mechanics should also be checked (Nanni, 2017), due to the relationship between these structures. The Thomas test can be positive (Malanga \& Mautner, 2017). The differential diagnosis should be made with hip intra-articular orthopaedic pathologies (femoroacetabular impingement syndrome, acetabular labrum tears, femoral head edema), and with systemic conditions (rheumatic or nonrheumatic osteoarthritis). Other differential diagnoses include insertional tendinopathies, proximal myotendinous lesions of the hip flexors (rectus femoris and sartorius) and distal myotendinous lesions of the abdominal muscle (K. Anderson et al., 2001) (Generini \& Matucci-Cerinic, 1993). MRI is the gold standard in the psoas tendinopathy evaluation and is particularly useful in the differential diagnosis (De Paulis et al., 1998) (Shin et al., 1996).

As for other tendinopathies, most patients benefit from conservative treatment (Johnston et al., 1998). Eccentric exercise is an appropriate method to use in the rehabilitation of iliopsoas tendinopathy, as seen in runners (Rauseo, 2017). Rehabilitation treatment is divided into five steps, according to Nanni et al. (Nanni, 2017): pain, swelling, and inflammation reduction; range of motion and extensibility recovery; strength and resistance recovery; coordination and proprioception recovery; specific technical movements and athletic sport-specific parameters recovery. Electrical stimulation was used to create muscular balance and correct muscle dysfunction in this syndrome (Edelstein, 2009). Surgery is required only in cases where pain is not resolved (thus failing to resume sport activities), or when suffering from a painful and debilitating internal 
snapping hip: it consists of an endoscopically tendon release (llizaliturri \& Camacho-Galindo, 2010) (S. A. Anderson \& Keene, 2008).

\section{CONCLUSION}

Hip tendinopathies are a common musculoskeletal disorder in sportive and sedentary population. Their management is complex and mainly conservative. Surgery is required only in subjects with no improvement over several months.

A physiotherapy approach is mandatory in these diseases and, differently from neurological rehabilitation, it is often related to clinical positive results for patient and for therapists' satisfaction (Corrado et al., 2019), often reaching a complete functional recovery. Differential diagnosis of these diseases is difficult. Beyond musculoskeletal conditions, some general diseases could determine similar signs and symptoms. A detailed clinical evaluation is required before the treatment and it is necessary to define the most appropriate diagnosis to plan a specific therapeutic program.

It is desirable to strength the preventive concept of different kind of exercise and physical activity, widely recognized as an effective therapeutic tool in different pathological conditions (Viña et al., 2012) (Williamson \& Pahor, 2010) (Palermi et al., 2020) (Montesano \& Mazzeo, 2019) (Valle et al., 2020), able to reduce the occurrence of significant tendinopathies and to reduce the time of treatment.

\section{REFERENCES}

Abbah, S. A., Spanoudes, K., O'Brien, T., Pandit, A., \& Zeugolis, D. I. (2014, March 18). Assessment of stem cell carriers for tendon tissue engineering in pre-clinical models. Stem Cell Research and Therapy. BioMed Central Ltd. https://doi.org/10.1186/scrt426

Ahmad, C. S., Redler, L. H., Ciccotti, M. G., Maffulli, N., Longo, U. G., \& Bradley, J. (2013). Evaluation and management of hamstring injuries. The American Journal of Sports Medicine, 41(12), 29332947. https://doi.org/10.1177/0363546513487063

Andarawis-Puri, N., Flatow, E. L., \& Soslowsky, L. J. (2015). Tendon basic science: Development, repair, regeneration, and healing. In Journal of Orthopaedic Research (Vol. 33, pp. 780-784). John Wiley and Sons Inc. https://doi.org/10.1002/jor.22869

Anderson, C. N. (2016). Iliopsoas: Pathology, Diagnosis, and Treatment. Clinics in Sports Medicine, 35(3), 419-433. https://doi.org/10.1016/j.csm.2016.02.009

Anderson, K., Strickland, S., \& Warren, R. (2001). Hip and groin injuries in athletes. The American Journal of Sports Medicine, 29, 521-533. https://doi.org/10.1177/03635465010290042501

Anderson, S. A., \& Keene, J. S. (2008). Results of arthroscopic iliopsoas tendon release in competitive and recreational athletes. The American Journal of Sports Medicine, 36(12), 2363-2371. https://doi.org/10.1177/0363546508322130

Ardigò, L. P., Palermi, S., Padulo, J., Dhahbi, W., Russo, L., Linetti, S., ... Tomljanovic, M. (2020). External Responsiveness of the SuperOpTM Device to Assess Recovery After Exercise: A Pilot Study. Frontiers in Sports and Active Living, 2, 67. https://doi.org/10.3389/fspor.2020.00067

Ashby, E. C. (1994). Chronic obscure groin pain is commonly caused by enthesopathy: 'Tennis elbow' of the groin. British Journal of Surgery, 81(11), 1632-1634. https://doi.org/10.1002/bjs.1800811123

Avrahami, D., \& Choudur, H. N. (2010). Adductor tendinopathy in a hockey player with persistent groin pain: a case report. The Journal of the Canadian Chiropractic Association, 54(4), 264-270. Retrieved from http://www.ncbi.nlm.nih.gov/pubmed/21120018 
Batista, F., Nery, C., Pinzur, M., Monteiro, A. C., de Souza, E. F., Felippe, F. H. Z., ... Campos, R. S. (2008). Achilles tendinopathy in diabetes mellitus. Foot \& Ankle International, 29(5), 498-501. https://doi.org/10.3113/FAl-2008-0498

Benazzo, F., Marullo, M., Zanon, G., Indino, C., \& Pelillo, F. (2013). Surgical management of chronic proximal hamstring tendinopathy in athletes: A 2 to 11 years of follow-up. Journal of Orthopaedics and Traumatology, 14(2), 83-89. https://doi.org/10.1007/s10195-013-0226-2

Beyer, R., Kongsgaard, M., Hougs Kjær, B., Øhlenschlæger, T., Kjær, M., \& Magnusson, S. P. (2015). Heavy Slow Resistance Versus Eccentric Training as Treatment for Achilles Tendinopathy: A Randomized Controlled Trial. The American Journal of Sports Medicine, 43(7), 1704-1711. https://doi.org/10.1177/0363546515584760

Biedert, R. M., Warnke, K., \& Meyer, S. (2003). Symphysis syndrome in athletes: surgical treatment for chronic lower abdominal, groin, and adductor pain in athletes. Clinical Journal of Sport Medicine : Official Journal of the Canadian Academy of Sport Medicine, 13(5), 278-284. https://doi.org/10.1097/00042752-200309000-00002

Bird, P. A., Oakley, S. P., Shnier, R., \& Kirkham, B. W. (2001). Prospective evaluation of magnetic resonance imaging and physical examination findings in patients with greater trochanteric pain syndrome. Arthritis and Rheumatism, 44(9), 2138-2145. https://doi.org/10.1002/15290131(200109)44:9<2138::AID-ART367>3.0.CO;2-M

Braun, P., \& Jensen, S. (2007). Hip pain - A focus on the sporting population. Australian Family Physician, $36,406-408,410$.

Brunker, P., Clarsen, B., Cook, J., Colls, A., Croosley, K., Hutchinson, M., ... Kahn, K. (2017). Brunker \& Kahn's Clinical sports medicine injuries volume 1. (Clinical Sports Medicine Collection | McGrawHill Medical, Ed.) (5e ed.). https://doi.org/617.1027

Brunot, S., Dubeau, S., Laumonier, H., Creusé, A., Delmeule, T., Reboul, G., ... Bouin, H. (2013). Acute inguinal pain associated with iliopectineal bursitis in four professional soccer players. Diagnostic and Interventional Imaging, 94(1), 91-94. https://doi.org/10.1016/j.diii.2012.10.009

Bui, K. L., Ilaslan, H., Recht, M., \& Sundaram, M. (2008). Iliopsoas injury: an MRI study of patterns and prevalence correlated with clinical findings. Skeletal Radiology, 37(3), 245-249. https://doi.org/10.1007/s00256-007-0414-3

Cacchio, A., Borra, F., Severini, G., Foglia, A., Musarra, F., Taddio, N., \& De Paulis, F. (2012). Reliability and validity of three pain provocation tests used for the diagnosis of chronic proximal hamstring tendinopathy. British Journal of Sports Medicine, 46(12), 883-887. https://doi.org/10.1136/bjsports2011-090325

Chi, A. S., Long, S. S., Zoga, A. C., Read, P. J., Deely, D. M., Parker, L., \& Morrison, W. B. (2015). Prevalence and pattern of gluteus medius and minimus tendon pathology and muscle atrophy in older individuals using MRI. Skeletal Radiology, 44(12), 1727-1733. https://doi.org/10.1007/s00256$\underline{015-2220-7}$

Chowdhury, R., Naaseri, S., Lee, J., \& Rajeswaran, G. (2014). Imaging and management of greater trochanteric pain syndrome. Postgraduate Medical Journal, 90(1068), 576-581. https://doi.org/10.1136/postgradmedj-2013-131828

Connell, D. A., Bass, C., Sykes, C. A. J., Young, D., \& Edwards, E. (2003). Sonographic evaluation of gluteus medius and minimus tendinopathy. European Radiology, 13(6), 1339-1347. https://doi.org/10.1007/s00330-002-1740-4

Cook, J. L., \& Docking, S. I. (2015, December). "Rehabilitation will increase the 'capacity' of your ....insert musculoskeletal tissue here...." Defining 'tissue capacity': a core concept for clinicians. British Journal of Sports Medicine. England. https://doi.org/10.1136/bjsports-2015-094849 
Cook, J. L., \& Purdam, C. R. (2009). Is tendon pathology a continuum? A pathology model to explain the clinical presentation of load-induced tendinopathy. British Journal of Sports Medicine, 43(6), 409416. https://doi.org/10.1136/bjsm.2008.051193

Cook, J. L., \& Purdam, C. R. (2014). The challenge of managing tendinopathy in competing athletes. British Journal of Sports Medicine, 48(7), 506-509. https://doi.org/10.1136/bjsports-2012-092078

Coombes, B. K., Bisset, L., Brooks, P., Khan, A., \& Vicenzino, B. (2013). Effect of Corticosteroid Injection, Physiotherapy, or Both on Clinical Outcomes in Patients With Unilateral Lateral Epicondylalgia: A Randomized Controlled Trial. JAMA, 309(5), 461-469. https://doi.org/10.1001/jama.2013.129

Corrado, B, Albano, M., Caprio, M. G., Di Luise, C., Sansone, M., Servodidio, V., ... Servodio lammarrone, C. (2019). Usefulness of point shear wave elastography to assess the effects of extracorporeal shockwaves on spastic muscles in children with cerebral palsy: An uncontrolled experimental study. Muscles, Ligaments and Tendons Journal, 9(1), 124-130. https://doi.org/10.32098/mlti.01.2019.04

Corrado, Bruno, Ciardi, G., Fortunato, L., \& lammarrone, C. (2019). Burnout syndrome among Italian physiotherapists: a cross-sectional study. European Journal of Physiotherapy, 1-6. https://doi.org/10.1080/21679169.2018.1536765

Corrado, Bruno, Ciardi, G., \& lammarrone, C. S. (2019). Rehabilitation management of Pompe disease, from childhood trough adulthood: A systematic review of the literature. Neurology International, 11(2), 7983. https://doi.org/10.4081/ni.2019.7983

Corrado, Bruno, Mazzuoccolo, G., Liguori, L., Chirico, V. A., Costanzo, M., Bonini, I., ... Curci, L. (2019). Treatment of lateral epicondylitis with collagen injections: A pilot study. Muscles, Ligaments and Tendons Journal, 9(4), 584-589. https://doi.org/10.32098/mltj.04.2019.14

Cushman, D., \& Rho, M. E. (2015). Conservative Treatment of Subacute Proximal Hamstring Tendinopathy Using Eccentric Exercises Performed With a Treadmill: A Case Report. The Journal of Orthopaedic and Sports Physical Therapy, 45(7), 557-562. https://doi.org/10.2519/jospt.2015.5762

D'Addona, A, Somma, D., Formisano, S., Rosa, D., Di Donato, S. L., \& Maffulli, N. (2016). Heat shock induces the expression of pro-inflammatory cytokines in human Achilles tendon tenocytes. Journal of Biological Regulators and Homeostatic Agents, 30(4 Suppl 1), 115-122.

D'Addona, Alessio, Maffulli, N., Formisano, S., \& Rosa, D. (2017). Inflammation in tendinopathy. The Surgeon, 15. https://doi.org/10.1016/j.surge.2017.04.004

Dallaudière, B., Pesquer, L., Meyer, P., Silvestre, A., Perozziello, A., Peuchant, A., ... Serfaty, J. M. (2014). Intratendinous injection of platelet-rich plasma under US guidance to treat tendinopathy: a long-term pilot study. Journal of Vascular and Interventional Radiology: JVIR, 25(5), 717-723. https://doi.org/10.1016/j.jvir.2014.01.026

Davenport, K. L., Campos, J. S., Nguyen, J., Saboeiro, G., Adler, R. S., \& Moley, P. J. (2015). UltrasoundGuided Intratendinous Injections With Platelet-Rich Plasma or Autologous Whole Blood for Treatment of Proximal Hamstring Tendinopathy: A Double-Blind Randomized Controlled Trial. Journal of Ultrasound in Medicine: Official Journal of the American Institute of Ultrasound in Medicine, 34(8), 1455-1463. https://doi.org/10.7863/ultra.34.8.1455

De Paulis, F., Cacchio, A., Michelini, O., Damiani, A., \& Saggini, R. (1998). Sports injuries in the pelvis and hip: diagnostic imaging. European Journal of Radiology, 27 Suppl 1, S49-59. https://doi.org/10.1016/s0720-048x(98)00043-6

De Smet, A. A., Blankenbaker, D. G., Alsheik, N. H., \& Lindstrom, M. J. (2012). MRI appearance of the proximal hamstring tendons in patients with and without symptomatic proximal hamstring tendinopathy. AJR. American Journal of Roentgenology, 198(2), 418-422. https://doi.org/10.2214/AJR.11.6590 
Degen, R. M. (2019, June 15). Proximal Hamstring Injuries: Management of Tendinopathy and Avulsion Injuries. Current Reviews in Musculoskeletal Medicine. Humana Press Inc. https://doi.org/10.1007/s12178-019-09541-x

Del Buono, A., Papalia, R., Khanduja, V., Denaro, V., \& Maffulli, N. (2012). Management of the greater trochanteric pain syndrome: a systematic review. British Medical Bulletin, 102, 115-131. https://doi.org/10.1093/bmb/ldr038

Dydyk, A. M., \& Sapra, A. (2020). Psoas Syndrome. StatPearls. StatPearls Publishing. Retrieved from http://www.ncbi.nlm.nih.gov/pubmed/31869165

Edelstein, J. (2009). Rehabilitating psoas tendonitis: A case report. HSS Journal, 5(1), 78-82. https://doi.org/10.1007/s11420-008-9097-0

Fader, R. R., Mitchell, J. J., Traub, S., Nichols, R., Roper, M., Dan, O. M., \& McCarty, E. C. (2014). Platelet-rich plasma treatment improves outcomes for chronic proximal hamstring injuries in an athletic population. Muscles, Ligaments and Tendons Journal, 4(4), 461-466. https://doi.org/10.11138/mlti/2014.4.4.461

Fearon, A. M., Cook, J. L., Scarvell, J. M., Neeman, T., Cormick, W., \& Smith, P. N. (2014). Greater trochanteric pain syndrome negatively affects work, physical activity and quality of life: a case control study. The Journal of Arthroplasty, 29(2), 383-386. https://doi.org/10.1016/j.arth.2012.10.016

Fearon, A. M., Scarvell, J. M., Neeman, T., Cook, J. L., Cormick, W., \& Smith, P. N. (2013). Greater trochanteric pain syndrome: defining the clinical syndrome. British Journal of Sports Medicine, 47(10), 649-653. https://doi.org/10.1136/bjsports-2012-091565

Feucht, M. J., Plath, J. E., Seppel, G., Hinterwimmer, S., Imhoff, A. B., \& Brucker, P. U. (2015). Gross anatomical and dimensional characteristics of the proximal hamstring origin. Knee Surgery, Sports Traumatology, Arthroscopy: Official Journal of the ESSKA, 23(9), 2576-2582. https://doi.org/10.1007/s00167-014-3124-0

Fitzpatrick, J., Bulsara, M. K., O'Donnell, J., \& Zheng, M. H. (2019). Leucocyte-Rich Platelet-Rich Plasma Treatment of Gluteus Medius and Minimus Tendinopathy: A Double-Blind Randomized Controlled Trial With 2-Year Follow-up. American Journal of Sports Medicine, 47(5), 1130-1137. https://doi.org/10.1177/0363546519826969

Fredericson, M., Moore, W., Guillet, M., \& Beaulieu, C. (2005). High Hamstring Tendinopathy in Runners Meeting the Challenges of Diagnosis, Treatment, and Rehabilitation. The Physician and Sportsmedicine, 33, 32-43. https://doi.org/10.3810/psm.2005.05.89

Fricker, P. A. (1997). Management of groin pain in athletes. British Journal of Sports Medicine. BMJ Publishing Group. https://doi.org/10.1136/bjsm.31.2.97

Frizziero, A., Vittadini, F., Pignataro, A., Gasparre, G., Biz, C., Ruggieri, P., \& Masiero, S. (2016). Conservative management of tendinopathies around hip. Muscles, Ligaments and Tendons Journal. CIC Edizioni Internazionali. https://doi.org/10.11138/mlti/2016.6.3.281

Ganderton, C., Semciw, A., Cook, J., Moreira, E., \& Pizzari, T. (2018). Gluteal Loading Versus Sham Exercises to Improve Pain and Dysfunction in Postmenopausal Women with Greater Trochanteric Pain Syndrome: A Randomized Controlled Trial. Journal of Women's Health (2002), 27(6), 815-829. https://doi.org/10.1089//wh.2017.6729

Generini, S., \& Matucci-Cerinic, M. (1993). lliopsoas bursitis in rheumatoid arthritis. Clinical and Experimental Rheumatology, 11(5), 549-551.

Genth, B., von Düring (Duering), M., von Engelhardt, L., Ludwig, J., Teske, W., \& von Schulze Pellengahr, C. (2012). Analysis of the Sensory Innervations of the Greater Trochanter for Improving the Treatment of Greater Trochanteric Pain Syndrome. Clinical Anatomy (New York, N.Y.), 25. https://doi.org/10.1002/ca.22035 
Goom, T. S. H., Malliaras, P., Reiman, M. P., \& Purdam, C. R. (2016). Proximal Hamstring Tendinopathy: Clinical Aspects of Assessment and Management. The Journal of Orthopaedic and Sports Physical Therapy, 46(6), 483-493. https://doi.org/10.2519/jospt.2016.5986

Grimaldi, A., Mellor, R., Hodges, P., Bennell, K., Wajswelner, H., \& Vicenzino, B. (2015). Gluteal Tendinopathy: A Review of Mechanisms, Assessment and Management. Sports Medicine (Auckland, N.Z.), 45(8), 1107-1119. https://doi.org/10.1007/s40279-015-0336-5

Hamming, M. G., Philippon, M. J., Rasmussen, M. T., Ferro, F. P., Turnbull, T. L., Trindade, C. A. C., ... Wijdicks, C. A. (2015). Structural properties of the intact proximal hamstring origin and evaluation of varying avulsion repair techniques: an in vitro biomechanical analysis. The American Journal of Sports Medicine, 43(3), 721-728. https://doi.org/10.1177/0363546514560878

Harvey, M. A., Singh, H., Obopilwe, E., Charette, R., \& Miller, S. (2015). Proximal hamstring repair strength: A biomechanical analysis at 3 hip flexion angles. Orthopaedic Journal of Sports Medicine, 3(4). https://doi.org/10.1177/2325967115576910

Heiderscheit, B., \& McClinton, S. (2016). Evaluation and Management of Hip and Pelvis Injuries. Physical Medicine and Rehabilitation Clinics of North America, 27(1), 1-29. https://doi.org/10.1016/i.pmr.2015.08.003

Ho, G. W. K., \& Howard, T. M. (2012). Greater trochanteric pain syndrome: more than bursitis and iliotibial tract friction. Current Sports Medicine Reports, 11(5), 232-238. https://doi.org/10.1249/JSR.0b013e3182698f47

Hölmich, P., Uhrskou, P., Ulnits, L., Kanstrup, I. L., Nielsen, M. B., Bjerg, A. M., \& Krogsgaard, K. (1999). Effectiveness of active physical training as treatment for long-standing adductor-related groin pain in athletes: randomised trial. Lancet (London, England), 353(9151), 439-443. https://doi.org/10.1016/S0140-6736(98)03340-6

Hopkins, C., Fu, S.-C., Chua, E., Hu, X., Rolf, C., Mattila, V. M., ... Chan, K.-M. (2016). Critical review on the socio-economic impact of tendinopathy. Asia-Pacific Journal of Sports Medicine, Arthroscopy, Rehabilitation and Technology, 4, 9-20. https://doi.org/10.1016/i.asmart.2016.01.002

Hsu, W. K. (2011). Outcomes following nonoperative and operative treatment for cervical disc herniations in National Football League athletes. Spine, 36(10), 800-805. https://doi.org/10.1097/BRS.0b013e3181e50651

llizaliturri, V. M. J., \& Camacho-Galindo, J. (2010). Endoscopic treatment of snapping hips, iliotibial band, and iliopsoas tendon. Sports Medicine and Arthroscopy Review, 18(2), 120-127. https://doi.org/10.1097/JSA.0b013e3181dc57a5

Jayaseelan, D. J., Moats, N., \& Ricardo, C. R. (2014). Rehabilitation of proximal hamstring tendinopathy utilizing eccentric training, lumbopelvic stabilization, and trigger point dry needling: 2 case reports. The Journal of Orthopaedic and Sports Physical Therapy, 44(3), 198-205. https://doi.org/10.2519/jospt.2014.4905

Jesus, J., Bryk, F., Moreira, V., Nakaoka, G., Curcio, A., \& Lucareli, P. (2015). Gluteus Maximus inhibition in proximal hamstring tendinopathy. Medicalexpress, 2, 1. https://doi.org/10.5935/MedicalExpress.2015.04.06

Johnston, C. A., Wiley, J. P., Lindsay, D. M., \& Wiseman, D. A. (1998). Iliopsoas bursitis and tendinitis. A review. Sports Medicine (Auckland, N.Z.), 25(4), 271-283. https://doi.org/10.2165/00007256$199825040-00005$

Kälebo, P., Karlsson, J., Swärd, L., \& Peterson, L. (1992). Ultrasonography of chronic tendon injuries in the groin. The American Journal of Sports Medicine, 20(6), 634-639. https://doi.org/10.1177/036354659202000603 
Kaux, J. F., Forthomme, B., le Goff, C., Crielaard, J. M., \& Croisier, J. L. (2011, June). Current opinions on tendinopathy. Journal of Sports Science and Medicine. Dept. of Sports Medicine, Medical Faculty of Uludag University. Retrieved from http://www.jssm.org

Khan, K. M., Cook, J. L., Bonar, F., Harcourt, P., \& Astrom, M. (1999). Histopathology of common tendinopathies. Update and implications for clinical management. Sports Medicine (Auckland, N.Z.), 27(6), 393-408. https://doi.org/10.2165/00007256-199927060-00004

Kingzett-Taylor, A., Tirman, P. F. J., Feller, J., McGann, W., Prieto, V., Wischer, T., ... Genant, H. K. (1999). Tendinosis and tears of gluteus medius and minimus muscles as a cause of hip pain: MR imaging findings. American Journal of Roentgenology, 173(4), 1123-1126. https://doi.org/10.2214/ajr.173.4.10511191

Knobloch, K. (2016). Drug-induced tendon disorders. In Advances in Experimental Medicine and Biology (Vol. 920, pp. 229-238). Springer New York LLC. https://doi.org/10.1007/978-3-319-33943-6_22

Labrosse, J. M., Cardinal, E., Leduc, B. E., Duranceau, J., Rémillard, J., Bureau, N. J., ... Brassard, P. (2010). Effectiveness of ultrasound-guided corticosteroid injection for the treatment of gluteus medius tendinopathy. AJR. American Journal of Roentgenology, 194(1), 202-206. https://doi.org/10.2214/AJR.08.1215

Laible, C., Swanson, D., Garofolo, G., \& Rose, D. J. (2013). lliopsoas syndrome in dancers. Orthopaedic Journal of Sports Medicine, 1(3). https://doi.org/10.1177/2325967113500638

Lempainen, L., Johansson, K., Banke, I. J., Ranne, J., Mäkelä, K., Sarimo, J., ... Orava, S. (2015). Expert opinion: Diagnosis and treatment of proximal hamstring tendinopathy. Muscles, Ligaments and Tendons Journal, 5(1), 23-28. https://doi.org/10.32098/mltj.01.2015.05

Lievense, A., Bierma-Zeinstra, S., Schouten, B., Bohnen, A., Verhaar, J., \& Koes, B. (2005). Prognosis of trochanteric pain in primary care. The British Journal of General Practice : The Journal of the Royal College of General Practitioners, 55(512), 199-204.

Littlewood, C., Malliaras, P., \& Chance-Larsen, K. (2015). Therapeutic exercise for rotator cuff tendinopathy: a systematic review of contextual factors and prescription parameters. International Journal of Rehabilitation Research. Internationale Zeitschrift Fur Rehabilitationsforschung. Revue Internationale de Recherches de Readaptation, 38(2), 95-106. https://doi.org/10.1097/MRR.0000000000000113

Loiacono, C., Palermi, S., Massa, B., Belviso, I., Romano, V., Di Gregorio, A., ... Sacco, A. M. (2019, August 1). Tendinopathy: Pathophysiology, therapeutic options, and role of nutraceutics. a narrative literature review. Medicina (Lithuania). MDPI AG. https://doi.org/10.3390/medicina55080447

Long, S. S., Surrey, D. E., \& Nazarian, L. N. (2013). Sonography of greater trochanteric pain syndrome and the rarity of primary bursitis. AJR. American Journal of Roentgenology, 201(5), 1083-1086. https://doi.org/10.2214/AJR.12.10038

Lustenberger, D. P., Ng, V. Y., Best, T. M., \& Ellis, T. J. (2011). Efficacy of treatment of trochanteric bursitis: a systematic review. Clinical Journal of Sport Medicine : Official Journal of the Canadian Academy of Sport Medicine, 21(5), 447-453. https://doi.org/10.1097/JSM.0b013e318221299c

Malanga, G., \& Mautner, K. (2017). Musculoskeletal Physical Examination. Medicine \& Science in Sports \& Exercise, 49(8), 1754. https://doi.org/10.1249/mss.0000000000001347

Martens, M. A., Hansen, L., \& Mulier, J. C. (1987). Adductor tendinitis and musculus rectus abdominis tendopathy. The American Journal of Sports Medicine, 15(4), 353-356. https://doi.org/10.1177/036354658701500410

Mascaró, A., Cos, M. À., Morral, A., Roig, A., Purdam, C., \& Cook, J. (2018). Gestión de la carga en las tendinopatías: progresión clínica para tendinopatías de Aquiles y rotuliana. Apunts Medicina de l'Esport, 53(197), 19-27. https://doi.org/10.1016/j.apunts.2017.11.005 
Mccormack, J. R. (2012). The management of bilateral high hamstring tendinopathy with ASTYM $®$ treatment and eccentric exercise: A case report. Journal of Manual and Manipulative Therapy, 20(3), 142-146. https://doi.org/10.1179/2042618612Y.0000000003

Mellor, R., Grimaldi, A., Wajswelner, H., Hodges, P., Abbott, J. H., Bennell, K., \& Vicenzino, B. (2016). Exercise and load modification versus corticosteroid injection versus "wait and see" for persistent gluteus medius/minimus tendinopathy (the LEAP trial): A protocol for a randomised clinical trial. BMC Musculoskeletal Disorders, 17. https://doi.org/10.1186/s12891-016-1043-6

Mens, J., Inklaar, H., Koes, B. W., \& Stam, H. J. (2006). A new view on adduction-related groin pain. Clinical Journal of Sport Medicine : Official Journal of the Canadian Academy of Sport Medicine, 16(1), 15-19. https://doi.org/10.1097/01.jsm.0000180869.37673.7b

Milic, M., Erceg, M., Palermi, S., Iuliano, E., Borrelli, M., Cè, E., ... Padulo, J. (2020). Uphill walking at iso-efficiency speeds. Biology of Sport, 37(3), 247-253. https://doi.org/10.5114/biolsport.2020.95635

Montesano, P., Domenico, T., \& Mazzeo, F. (2016). The drop-outs in young players, 16.

Montesano, P., \& Mazzeo, F. (2019). Sports Activities in Obese Teenagers Improve Social Inclusion and Health. Sport Mont, 17, 55-60. https://doi.org/10.26773/smj.190210

Morton, S., Williams, S., Valle, X., Diaz-Cueli, D., Malliaras, P., \& Morrissey, D. (2017). Patellar Tendinopathy and Potential Risk Factors: An International Database of Cases and Controls. Clinical Journal of Sport Medicine : Official Journal of the Canadian Academy of Sport Medicine, 27(5), 468474. https://doi.org/10.1097/JSM.0000000000000397

Nanni, G. (2017). Iliopsoas Tendinopathy. In Groin Pain Syndrome (pp. 125-131). Springer International Publishing. https://doi.org/10.1007/978-3-319-41624-3_15

Oliva, F., Piccirilli, E., Berardi, A. C., Tarantino, U., \& Maffulli, N. (2016). Influence of Thyroid Hormones on Tendon Homeostasis. Advances in Experimental Medicine and Biology, 920, 133-138. https://doi.org/10.1007/978-3-319-33943-6_12

Palermi, S., Sacco, A. M., Belviso, I., Marino, N., Gambardella, F., Loiacono, C., \& Sirico, F. (2020). Effectiveness of Tai Chi on Balance Improvement in Type 2 Diabetes Patients: A Systematic Review and Meta-Analysis. Journal of Aging and Physical Activity, 1-11. https://doi.org/10.1123/japa.20190242

Palermi, S., Sacco, A. M., Belviso, I., Romano, V., Montesano, P., Corrado, B., \& Sirico, F. (2020). Guidelines for physical activity-a cross-sectional study to assess their application in the general population. Have we achieved our goal? International Journal of Environmental Research and Public Health, 17(11), 1-14. https://doi.org/10.3390/ijerph17113980

Podschun, L., Hanney, W. J., Kolber, M. J., Garcia, A., \& Rothschild, C. E. (2013). Differential diagnosis of deep gluteal pain in a female runner with pelvic involvement: a case report. International Journal of Sports Physical Therapy, 8(4), 462-471. Retrieved from https://pubmed.ncbi.nlm.nih.gov/24175132

Puranen, J., \& Orava, S. (1988). The hamstring syndrome. A new diagnosis of gluteal sciatic pain. The American Journal of Sports Medicine, 16(5), 517-521. https://doi.org/10.1177/036354658801600515

Rauseo, C. (2017). The rehabilitation of a runner with iliopsoas tendinopathy using an eccentric-biased exercise-a case report. International Journal of Sports Physical Therapy, 12(7), 1150-1162. https://doi.org/10.26603/ijspt20171150

Robinson, P., Barron, D. A., Parsons, W., Grainger, A. J., Schilders, E. M. G., \& O'Connor, P. J. (2004). Adductor-related groin pain in athletes: correlation of MR imaging with clinical findings. Skeletal Radiology, 33(8), 451-457. https://doi.org/10.1007/s00256-004-0753-2

Rosa, D., di Donato, S. L., Balato, G., D'Addona, A., \& Schonauer, F. (2016). Supinated forearm is correlated with the onset of medial epicondylitis in professional slalom waterskiers. Muscles, Ligaments and Tendons Journal, 6(1), 140-146. https://doi.org/10.11138/mlt/2016.6.1.140 
Schilders, E., Dimitrakopoulou, A., Cooke, M., Bismil, Q., \& Cooke, C. (2013). Effectiveness of a selective partial adductor release for chronic adductor-related groin pain in professional athletes. The American Journal of Sports Medicine, 41(3), 603-607. https://doi.org/10.1177/0363546513475790

Segal, N. A., Felson, D. T., Torner, J. C., Zhu, Y., Curtis, J. R., Niu, J., \& Nevitt, M. C. (2007). Greater trochanteric pain syndrome: epidemiology and associated factors. Archives of Physical Medicine and Rehabilitation, 88(8), 988-992. https://doi.org/10.1016/j.apmr.2007.04.014

Servodio lammarrone, C., Cadossi, M., Sambri, A., Grosso, E., Corrado, B., \& Servodio lammarrone, F. (2016). Is there a role of pulsed electromagnetic fields in management of patellofemoral pain syndrome? Randomized controlled study at one year follow-up. Bioelectromagnetics, 37(2), 81-88. https://doi.org/10.1002/bem.21953

Shbeeb, M. I., O'Duffy, J. D., Michet, C. J. J., O'Fallon, W. M., \& Matteson, E. L. (1996). Evaluation of glucocorticosteroid injection for the treatment of trochanteric bursitis. The Journal of Rheumatology, 23(12), 2104-2106.

Shin, A. Y., Morin, W. D., Gorman, J. D., Jones, S. B., \& Lapinsky, A. S. (1996). The superiority of magnetic resonance imaging in differentiating the cause of hip pain in endurance athletes. The American Journal of Sports Medicine, 24(2), 168-176. https://doi.org/10.1177/036354659602400209

Sirico, F., Ricca, F., DI Meglio, F., Nurzynska, D., Castaldo, C., Spera, R., \& Montagnani, S. (2017). Local corticosteroid versus autologous blood injections in lateral epicondylitis: meta-analysis of randomized controlled trials. European Journal of Physical and Rehabilitation Medicine, 53(3), 483491. https://doi.org/10.23736/S1973-9087.16.04252-0

Speers, C. J. B., \& Bhogal, G. S. (2017). Greater trochanteric pain syndrome: A review of diagnosis and management in general practice. British Journal of General Practice, 67(663), 479-480. https://doi.org/10.3399/bjgp17X693041

Stephens, M. B., Beutler, A. I., \& O'Connor, F. G. (2008). Musculoskeletal injections: a review of the evidence. American Family Physician, 78(8), 971-976.

Strauss, E. J., Nho, S. J., \& Kelly, B. T. (2010). Greater trochanteric pain syndrome. Sports Medicine and Arthroscopy Review, 18(2), 113-119. https://doi.org/10.1097/JSA.0b013e3181e0b2ff

Topol, G. A., \& Reeves, K. D. (2008). Regenerative injection of elite athletes with career-altering chronic groin pain who fail conservative treatment: a consecutive case series. American Journal of Physical Medicine \& Rehabilitation, 87(11), 890-902. https://doi.org/10.1097/PHM.0b013e31818377b6

Topol, G. A., Reeves, K. D., \& Hassanein, K. M. (2005). Efficacy of dextrose prolotherapy in elite male kicking-sport athletes with chronic groin pain. Archives of Physical Medicine and Rehabilitation, 86(4), 697-702. https://doi.org/10.1016/j.apmr.2004.10.007

Tyler, T. F., Fukunaga, T., \& Gellert, J. (2014). Rehabilitation of soft tissue injuries of the hip and pelvis. International Journal of Sports Physical Therapy, 9(6), 785-797.

Valle, E. Della, Palermi, S., Aloe, I., Marcantonio, R., Spera, R., Montagnani, S., \& Sirico, F. (2020, May 26). Effectiveness of workplace yoga interventions to reduce perceived stress in employees: $A$ systematic review and meta-analysis. Journal of Functional Morphology and Kinesiology. MDPI Multidisciplinary Digital Publishing Institute. https://doi.org/10.3390/jfmk5020033

Viña, J., Sanchis-Gomar, F., Martinez-Bello, V., \& Gomez-Cabrera, M. C. (2012, September). Exercise acts as a drug; The pharmacological benefits of exercise. British Journal of Pharmacology. WileyBlackwell. https://doi.org/10.1111/j.1476-5381.2012.01970.x

Vola, E. A., Albano, M., Di Luise, C., Servodidio, V., Sansone, M., Russo, S., ... Vallone, G. (2018). Use of ultrasound shear wave to measure muscle stiffness in children with cerebral palsy. Journal of Ultrasound, 21(3), 241-247. https://doi.org/10.1007/s40477-018-0313-6 
Wetzel, R. J., Patel, R. M., \& Terry, M. A. (2013). Platelet-rich plasma as an effective treatment for proximal hamstring injuries. Orthopedics, 36(1), e64-70. https://doi.org/10.3928/0147744720121217-20

Williamson, J., \& Pahor, M. (2010, January 25). Evidence regarding the benefits of physical exercise. Archives of Internal Medicine. NIH Public Access. https://doi.org/10.1001/archinternmed.2009.491

Wilson, J. J., \& Furukawa, M. (2014). Evaluation of the patient with hip pain. American Family Physician, 89(1), 27-34. Retrieved from www.aafp.org/afp

Zissen, M. H., Wallace, G., Stevens, K. J., Fredericson, M., \& Beaulieu, C. F. (2010). High hamstring tendinopathy: MRI and ultrasound imaging and therapeutic efficacy of percutaneous corticosteroid injection. AJR. American Journal of Roentgenology, 195(4), 993-998. https://doi.org/10.2214/AJR.09.3674 